\title{
PENGARUH PENDEKATAN OPEN-ENDED TERHADAP KEMAMPUAN BERPIKIR KREATIF DAN SELF ESTEEM SISWA MADRASAH ALIYAH DAAR AL ULUUM KISARAN
}

\author{
Muthia Dewi \\ Sekolah Tinggi Manajemen Informatika dan Komputer (STMIK ROYAL) Kisaran \\ Jalan Prof. H.M. Yamin No. 173 Kisaran Kab. Asahan \\ tiadaisu@gmail.com
}

\begin{abstract}
ABSTRAK
Penelitian ini bertujuan untuk mengetahui pengaruh pendekatan Open-ended terhadap kemampuan berpikir kreatif dan Sel-esteem siswa Pesantren Daar Al Uluum Asahan Tahun Pembelajaran 2014/2015 yang terdiri dari 2 kelas, yaitu kelas X-A sebagai kelas eksperimen dan kelas X-B sebagai kelas kontrol. Kelas eksperimen berjumlah 35 orang dan kelas kontrol berjumlah 35 orang. Instrumen yang digunakan untuk mengetahui hasil belajar siswa adalah tes hasil belajar. Instrumen yang digunakan untuk mengetahui aktivitas belajar siswa adalah lembar observasi. Hasil penelitian menunjukkan bahwa nilai rata-rata pretes kelas eksperimen 24,6 dan nilai rata-rata pretes kelas kontrol 25,8. Pada pengujian data pretes kedua kelas diperoleh bahwa data kedua kelas berdistribusi normal dan homogen. Hasil uji t pretes diperoleh t.hitung < t.tabel $(0,5<2,00)$ yang artinya bahwa kemampuan awal siswa pada kedua kelas sama. Kemudian diberi perlakuan dengan pendekatan pembelajaran open-ended. Setelah pendekatan openended diberikan diperoleh nilai postes siswa pada kelas eksperimen dengan rata-rata 59,12 sedangkan pada kelas kontrol diperoleh rata-rata 53,33. Berdasarkan hasil uji hipotesis diperoleh nilai t.hitung sebesar 3,7 dan t.tabel sebesar 2,00. Hasil ini menunjukkan bahwa Ha diterima yang menjelaskan bahwa adanya pengaruh yang signifikan penggunaan pendekatan pembelajaran open-ended terhadap hasil belajar siswa kelas X tahun pelajaran 2014/2015.
\end{abstract}

Kata Kunci : Pendekatan Open-Ended, Berpikir Kreatif, kemampuan,Self Esteem,siswa

\section{PENDAHULUAN}

Dalam proses kegiatan belajar-mengajayang dilaksanakan di sekolah, komponen yang paling penting untuk tercapainya keberhasilan tujuan pendidikan adalah guru. Guru dituntut harus dapat mengembangkan kemampuan siswa baik dari segi kognitif, afektif maupun psikomotorik. Untuk dapat memperoleh hal tersebut, dibutuhkan kemampuan berpikir kreatif, rasional dan kemauan bekerjasama dengan orang lain. Kegiatan berpikir dibutuhkan karena dapat memecahkan suatu persoalan dan menentukan strategi apa yang digunakan untuk memecahkan persoalan tersebut. Matematika merupakan alat untuk memajukan daya pikir manusia. Melalui matematika diharapkan siswa dapat mempunyai daya pikir logis, kreatif dan mampu bekerjasama dimasa yang akan datang. Ketika siswa dihadapkan pada persoalan, ketika itu siswa dituntut untuk menyelesaikan masalah tersebut. Siswa dituntut untuk mencari alternatif persoalan yang dihadapinya dengan menggunakan keterampilan berpikir. Persoalan matematika itu sendirilah yang dapat dijadikan sebagai alat memajukan daya pikirnya. Keterampilan yang ada pada siswa dalam menyelesaikan persoalan membentuk siswa menjadi kuat daya pikirnya seperti kemampuan memperoleh, mengelola, dan memanfaatkan informasi. Perkembangan optimal dari kemampuan berpikir kreatif ada kaitannya dengan cara mengajar seorang guru. Dalam proses pembelajaran, siswa diberi kesempatan dan kepercayaan untuk berpikir dan mengemukan ide baru. Kemampuan berpikir kreatif merupakan faktor kognitif dari kreativitas. Faktor kognitif adalah faktor yang berkaitan dengan ciri-ciri aptitude (kecerdasan) yaitu ciri-ciri yang meliputi kemampuan berpikir lancar, fleksibel (luwes), orisinil, elaborasi dan kemampuan evaluasi. Dalam kenyataannya, proses belajar-mengajar di sekolah pada umumnya guru hanya menyajikan informasi dan siswa hanya mendengarkan dan menerima apa yang disampaikan guru. Pembelajaran matematika selama ini lebih menekankan pada ceramah, menggunakan rumus dan mencari satu jawaban yang benar untuk soal- 
soal yang diberikan. Sedangkan proses pemikirin kreatif jarang sekali diberikan. Akibatnya siswa hanya mencontoh apa yang dikerjakan guru, tanpa makna dan pengertian sehingga dalam menyelesaikan soal siswa beranggapan cukup dikerjakan seperti apa yang dicontohkan. Hal tersebut menyebabkan siswa kurang memiliki kemampuan menyelesaikan masalah dengan alternatif lain. Siswa kurang memiliki kemampuan mencari alternatif lain dapat disebabkan karena siswa kurang memiliki kemampuan fleksibilitas yang merupakan komponen utama kemampuan berpikir kreatif.

Suherman, dkk (2003) berpendapat bahwa siswa yang meniru kerja dan cara menyelesaikan soal yang dilakukan oleh guru akan membuat siswa menjadi pasif dan tidak menumbuhkan kreatifitas. dapat berkembang dengan baik apabila guru tidak melibatkan siswa dalam menyelesaikan suatu persoalan dan masih menggunakan pembelajaran konvensional yaitu pembelajaran yang masih berpusat pada guru. Hal ini dapat membuat prestasi belajar siswa rendah. Rendahnya hasil belajar siswa salah satunya disebabkan karena pendekatan dan strategi yang digunakan seorang guru kurang memberikan kesempatan kepada siswa untuk mengembangkan pola pikirnya sesuai dengan kemampuannya masing-masing. Schoenfeld (1992) mengatakan bahwa perlu adanya perubahan dalam kurikulum dan pembelajaran matematika yang melibatkan usaha-usaha baru seperti dalam mencari jawaban (tidak hanya menghafal prosedur), menggali pola (tidak hanya mengingat), merumuskan konjektur (tidak hanya mengerjakan latihan).

Dalam hal ini, perlu kiranya pembelajaran yang dapat membuat siswa untuk berperan aktif dan menantang siswa dalam memahami materi pelajaran yang disampaikan sehingga dapat menumbuhkan semangat dan motivasi diri. Salah satu pendekatan dalam pembelajaran matematika yang dapat memberikan keleluasaan siswa untuk berpikir secara aktif dan kreatif adalah pendekatan open-ended. Heddens dan Speer (1995:30) menyatakan bahwa pendekatan open-ended bermanfaat untuk meningkatkan cara berpikir siswa. Pendekatan open-ended merupakan salah satu pendekatan yang membantu siswa melakukan pemecahan masalah secara kreatif dan menghargai keragaman berpikir yang mungkin timbul selama proses pemecahan masalah. Selain itu pendekatan open-ended dapat membuat siswa menghargai dirinya sendiri dan merasa lebih bermakna. Pendekatan open-ended merupakan bagian dari pembelajaran konstruktivisme. pendekatan open-ended, pengetahuan dikonstruksi oleh siswa itu sendiri dan dalam pembelajarannya disajikan suatu persoalan yang mempunyai beragam metode penyelesaian.

\section{TUJUAN KAJIAN}

Untuk mengetahui peningkatan kemampuan berpikir kreatif siswa yang memperoleh pendekatan openended lebih baik daripada siswa yang memperoleh pembelajaran konvensional.

Untuk mengetahui peningkatan self-esteem siswa yang memperoleh pendekatan open-ended lebih baik daripada siswa yang memperoleh pembelajaran konvensional

Untuk mengetahui proses penyelesaian masalah yang dibuat oleh siswa dalam menyelesaikan masalah pada Pendekatan open-ended dan Pendekatan Pembelajaran Konvensional.

\section{OBJEKTIF KAJIAN}

Berdasarkan masalah tersebut, maka objektif kajian penelitian ini secara umum adalah mengetahui dan memahami keanekaragaman siswa dalam menyelesaikan persoalan berbeda-beda. Pendekatan ini tidak mengharuskan siswa untuk menghafal fakta-fakta tetapi mengharuskan siswa mengkonstruksi pengetahuan didalam pikiran mereka sendiri. Pendekatan ini membiasakan siswa untuk memecahkan masalah, menemukan sesuatu yang berguna bagi dirinya sendiri dan bergelut dengan ide-ide. Kajian ini memberikan kesempatan kepada siswa untuk berinovasi dengan ide-ide dan cara yang berbeda. Pendekatan ini dapat menjadi fasilitator dalam mengembangkan dan merangsang kemampuan berpikir kreatif siswa. Apabila siswa diberi suatu persoalan open-ended maka siswa akan dapat membuat kesimpulan sendiri yang pada akhirnya membuat semangat dan motivasi diri mereka meningkat, keberhasilan dan prestasi belajar meningkat.

Adapun objektif kajian penelitian ini secara khusus adalah:

Apakah peningkatan kemampuan berpikir kreatif siswa yang memperoleh pendekatan open-ended lebih baik daripada siswa yang memperoleh pembelajaran secara konvensional? 
Apakah peningkatan self-esteem siswa yang memperoleh pendekatan open-ended lebih baik daripada siswa yang memperoleh pembelajaran secara konvensional?

Bagaimanakah proses penyelasaian masalah yang dibuat oleh siswa dalam menyelesaikan masalah pada Pendekatan open-ended dan Pendekatan Pembelajaran secara Konvensional?

\section{TINJAUAN PUSTAKA}

\section{Pengertian Berpikir}

Proses berpikir berkaitan erat dengan dengan jenis perilaku lain dan memerlukan keterlibatan aktif dari pemikir. Berpikir berkaitan erat dengan apa yang terjadi di dalam otak manusia dan fakta-fakta yang ada dalam dunia (Presseisen dalam Somakim, 2010). Resnick (dalam Ratnaningsih, 2007) menyatakan bahwa berpikir adalah suatu proses yang melibatkan operasi mental seperti klasifikasi, induksi, deduksi dan penalaran. Ibrahim dan Nur (dalam Ratnaningsih, 2007) menyatakan bahwa berpikir adalah suatu proses yang kompleks dan non-algoritmik untuk menganalisis, mengkritik dan mencapai kesimpulan berdasarkan pada pertimbangan yang seksama. Berpikir meliputi dua aspek yang utama yaitu kritis dan kreatif. Keduanya menggunakan penalaran untuk membangun berbagai ide. Sumarno (2005) mengatakan secara umum berpikir matematik dapat diartikan sebagai melaksanakan kegiatan atau proses matematika (doing math) atau tugas matematik (mathematical task). Berpikir matematik dapat digolongkan dalam dua jenis yaitu berpikir matematik tingkat rendah (low-order mathematical thingking) dan berpikir matematik tingkat tinggi (high-order mathematical thingking). Berpikir kritis dan kreatif matematik, keduanya merupakan jenis berpikir yang termasuk pada berpikir matematik tingkat tinggi.

\section{Berpikir Kreatif}

Krutetski (Part, 2004) mendefinisikan kemampuan berpikir kreatif matematis sebagai kemampuan menemukan solusi masalah matematis secara mudah dan fleksibel. Menurut Livne (2008) berpikir kreatif matematis merujuk pada kemampuan untuk menghasilkan solusi bervariasi yang bersifat baru terhadap masalah yang bersifat terbuka. Berdasarkan kedua pendapat dapat disimpulkan berpikir kreatif matematis merupakan kemampuan siswa dalam memecahkan seuatu permasalahan matematis yang sifatnya terbuka dengan memunculkan ide-ide yang baru dan bersifat fleksibel.

Guilford (dalam Supriadi, 1997:7) mengemukakan sifat-sifat yang menjadi ciri kemampuan berpikir kreatif, yaitu kelancaran (fluency), keluwesan (flexibility), keaslian (originality), penguraian (elaboration), perumusan kembali (redefinition).

Kelancaran (fluency)

Kelancaran adalah kemampuan untuk memberikan berbagai respon. Kelancaran pada umumnya berkaitan dengan kemampuan melahirkan alternatif-alternatif pada saat diperlukan.

Keluwesan (flexibility)

Keluwesan adalah kemampuan untuk mengemukakan berbagai macam pemecahan dan pendekatan terhadap masalah. Keluwesan berkaitan dengan kemampuan untuk membuat variasi terhadap satu ide dan kemampuan memperoleh cara baru.

Keaslian (originality)

Keaslian adalah kemampuan untuk mencetuskan gagasan dengan cara-cara yang asli, tidak klise. Keaslian berkaitan dengan kemampuan memberikan respon yanag khas/unik yang berbeda dengan yang biasa dilakukan orang lain.

Penguraian (elaboration)

Penguraian adalah kemampuan untuk menguraikan sesuatu secara lebih terperinci. Elaborasi atau penguraian bisa juga merupakan penambahan detail atau keterangan terhadap ide yang sudah ada.

Perumusan kembali (redefinition)

Perumusan kembali merupakan kemampuan untuk meninjau suatu persoalan berdasarkan perspektif yang berbeda dengan apa yang sudah diketahui oleh banyak orang.

Bishop (dalam Pehkonen, 1997) mengatakan bahwa dalam matematika seseorang memerlukan dua jenis berpikir yang saling komplemen yaitu berpikir kreatif yang disamakan dengan intuisi dan berpikir analitis yang disamakan dengan logika. Intuisi dikaitkan dengan visualitas dan logika dikaitkan dengan verbalitas. Krutetskii (1976) menyamakan kreativitas matematika dengan keberbakatan 
matematika. Menurut Krutetskii, kreativitas dalam memecahkan masalah matematika dikarakteristikkan dengan kemampuan siswa dalam merumuskan masalah matematika secara bebas, bersifat penemuan dan baru. Ide-ide tersebut sejalan dengan ide-ide seperti fleksibilitas, kelancaran (fluency), membuat asosiasi baru, dan menghasilkan jawaban divergen yang berkaitan dengan kreativitas secara umum.

\section{Self Esteem dalam Matematika}

Maslow (2008) menyatakan bahwa ada dua bentuk kebutuhan dari self esteem (1) kebutuhan untuk mendapatkan pengakuan dari orang lain; (2) kebutuhan mendapatkan pengakuan dari dirinya sendiri. Barnabas (2008) menggolongkan self esteem sebagai bagian dari self concept. Ia menyatakan bahwa self concept memiliki tiga komponen utama, yaitu:

1. Self Ideal (diri ideal)

Self ideal adalah sosok seperti apa yang paling diinginkan seseorang untuk menjadi dirinya di segala bidang kehidupannya.

2. Self Image (citra diri)

Bagian ini menunjukkan bagaimana seseorang membayangkan dirinya sendiri.

3. Self Esteem (harga diri)

Definisi paling tepat untuk menggambarkan self esteem adalah seberapa besar seseorang menyukai dirinya sendiri.

Self esteem adalah bagaimana seseorang merasakan diri sendiri akan mempengaruhi bagaimana mereka bertingkah laku, penilaian seseorang mengenai penghargaan terhadap dirinya dan perasaan yang berhubungan dengan penilaian tersebut. Tingkat self esteem seseorang ditentukan oleh tingkat kepercayaan atau keyakinan pada diri sendiri, baik dalam penampilan fisik maupun dalam kemampuan serta interaksi dengan lingkungannya. Dengan adanya self esteem yang positif memberikan peluang bagi para siswa untuk melakukan evaluasi terhadap dirinya yang mengacu pada penilaian mengenai betapa pentingnya dirinya. Self esteem yang rendah akan menjadikan siswa sulit dalam menyesuaikan diri dalam pelajaran. Telah dijelaskan bahwa prestasi belajar dan self esteem saling mempengaruhi. Salah satu cara meningkatkan self esteem siswa adalah dengan cara meningkatkan prestasi belajar siswa, tetapi dengan meningkatnya prestasi belajar tidak langsung meningkatkan self esteem siswa karena banyak faktor lain yang mempengaruhinya.

\section{Pendekatan Open-Ended}

Shimada (1997:1) menyatakan bahwa Pendekatan open-ended merupakan pendekatan pembelajaran yang menyajikan suatu permasalahan yang memiliki lebih dari satu metoda penyelesaian. Pendekatan openended mulai dikembangkan di Jepang pada tahun 70-an, dan semenjak itu guru-guru di Jepang menggunakan pendekatan ini dalam pembelajaran matematika di sekolah. Hashimoto (1997) mengatakan bahwa metoda pembelajaran yang dapat digunakan untuk meningkatkan kreativitas matematik di lingkungan sekolah adalah pendekatan open-ended. Dalam pelaksanaannya dilakukan melalui kegiatan membahas dan memecahkan masalah, Pendekatan ini memberi keleluasaan kepada siswa untuk mengemukakan jawaban secara aktif dan kreatif.

\begin{tabular}{|l|l|l|}
\hline No & Fase Pembelajaran & Kegiatan Pembelajaran \\
\hline 1 & Menyajikan masalah & $\begin{array}{l}\text { Memberikan problem terbuka kepada siswa, sehingga } \\
\text { siswa mendapatkan kesempatan untuk melakukan segala } \\
\text { sesuatu secara bebas sesuai kehendak mereka. }\end{array}$ \\
\hline 2 & $\begin{array}{l}\text { PPengorganisasian } \\
\text { pembelajaran }\end{array}$ & $\begin{array}{l}\text { Guru mengarahkan siswa untuk menumbuhkan } \\
\text { orisinilitas ide, kreativitas, kognitif tinggi, kritis, } \\
\text { komunikasi-interaksi, sharing, keterbukaan, dan } \\
\text { sosialisasi. }\end{array}$ \\
\hline
\end{tabular}




\begin{tabular}{|l|l|lr|}
\hline 3 & & $\begin{array}{l}\text { Guru harus menyiapkan atau menuliskan daftar antisipasi } \\
\text { siswa } \\
\text { respons } \\
\text { masalah. Sehingga siswa dapat mengekpresikan ide atau } \\
\text { siswa } \\
\text { pikirannya sebagai upaya mengarahkan dan membantu } \\
\text { siswa memecahkan masalah sesuai dengan cara } \\
\text { kemampuannya. }\end{array}$ \\
\hline 4 & Bimbingan dan pengarahan & $\begin{array}{l}\text { Guru memberikan bimbingan dan arahan } \\
\text { kepada siswa untuk } \\
\text { berimprovisasi mengembangkan metode, cara, atau } \\
\text { pendekatan yang bervariasi dalam memperoleh jawaban } \\
\text { sehingga jawaban siswa beragam }\end{array}$ \\
\hline 5 & Membuat kesimpulan. & $\begin{array}{l}\text { Siswa diminta untuk menjelaskan proses mencapai } \\
\text { jawaban tersebut }\end{array}$ \\
\hline
\end{tabular}

(Sumber : Suyatno, Model-Model Pembelajaran beserta Sintaksnya)

\section{METODE PENELITIAN}

Jenis penelitian yang digunakan adalah jenis penelitian eksperimen. dimana penelitian ini menggunakan eksperimen pendekatan pembelajaran open-ended. Penelitian di laksanakan di Madrasah Aliyah Pesantren Daar Al Uluum Asahan Tahun Pembelajaran 2014/2015. Waktu penelitian berlangsung pada bulan Oktober 2014- September 2015. Sampel penelitian adalah seluruh siswa kelas X MA Pesantren Daar Al Uluum Asahan Tahun Pembelajaran 2014/2015 yang terdiri dari dua kelas dengan jumlah siswa 70 orang. Untuk melihat pengaruh pendekatan open-ended dan Konvensional dapat dibandingkan dengan tabel dibawah ini

\begin{tabular}{|l|l|l|l|}
\hline Kelas & $\begin{array}{l}\text { Pra } \\
\text { Perlakuan }\end{array}$ & Tindakan & Setelah Tindakan \\
\hline X-A & Pre Test & $\begin{array}{l}\text { Pendekatan open- } \\
\text { ended }\end{array}$ & Post tes \\
\hline X-B & Pre Test & Konvensional & Pos test \\
\hline
\end{tabular}

Penelitian ini menggunakan dua variabel yakni variabel bebas dan variabel terikat. Sebagai variabel bebas adalah penerapan pembelajaran open-ended dan konvensional sedangkan variabel terikat adalah hasil belajar matematika siswa. Sedangkan indikator dalam penelitian ini adalah skor test dalam mengikuti pembelajaran matematika dengan penerapan pembelajaran open-ended.

Alat pengumpul data dalam penelitian ini adalah dengan memberikan tes sebanyak 20 soal dalam bentuk pilihan ganda. Sebelum dilaksanakan penelitian kepada sampel, tes yang telah disusun terlebih dahulu diuji cobakan, dengan menghitung indeks kesukaran, daya pembeda, tingkat validitas dan tingkat reliabilitas.

\section{a. Taraf Kesukaran Tes}

Untuk mengukur taraf kesukaran soal, digunakan rumus:

$\mathrm{P}=\frac{B}{J S} \quad$ (Arikunto,2003:208).

Keterangan :

$\mathrm{P}=$ indeks kesukaran.

$\mathrm{B}=$ banyaknya siswa yang menjawab soaldengan betul.

$\mathrm{JS}=$ jumlah seluruh siswa peserta tes. 
Dengan klasifikasi sebagai berikut :

$\mathrm{P}=0,00-0,30=$ Soal sukar

$\mathrm{P}=0,30-0,70=$ Soal sedang

$\mathrm{P}=0,70-1,00=$ Soal mudah

b. Daya Pembeda

Untuk menghitung daya pembeda soal digunakan rumus :

$\mathrm{DP}=\frac{B A}{J A}-\frac{B B}{J B}=P A-P B$

(Arikunto, $2003: 213$ )

Kriteria indeks daya pembeda :

$\mathrm{D}=0,00-0,20=$ jelek

$\mathrm{D}=0,20-0,40=$ cukup

$\mathrm{D}=0,40-0,70=$ baik

$\mathrm{D}=0,70-1,00 \quad=$ baik sekali

$\mathrm{D}=<0,00 \quad=$ jelek sekali

c. Uji Validitas

Menurut Arikunto (2003:72) untuk menghitung validitas dengan rumus:

$\mathrm{r}_{\mathrm{xy}}=\frac{N \sum X Y-\left(\sum X\right)\left(\sum Y\right)}{\sqrt{\left\{N \sum X^{2}-\left(\sum X\right)^{2}\right)\left\{N \sum Y^{2}-\left(\sum Y\right)^{2}\right\}}}$

Keterangan :

$\mathrm{r}_{\mathrm{xy}}=$ koefisien korelasi antara variabel $\mathrm{x}$ dan variabel $\mathrm{y}$

$\sum \mathrm{x} \quad=$ jumlah skor distribusi $\mathrm{x}$

$\sum \mathrm{y} \quad=$ jumlah skor total

$\sum \mathrm{xy} \quad=$ jumlah perkalian $\mathrm{x}$ dan $\mathrm{y}$

$\mathrm{N} \quad=$ jumlah responden

$\sum \mathrm{x}^{2} \quad=$ jumlah kuadrat skor distribusi

$\sum \mathrm{y}^{2} \quad=$ jumlah kuadrat total $\mathrm{y}$

Kriteria Keputusan : Jika $\mathrm{r}_{\mathrm{xy}}>\mathrm{r}_{\text {tabel }}$ maka item tersebut valid (Arikunto, 2003).

d. Uji Reliabilitas

Uji reliabilitas tes dapat ditentukan dengan rumus K-R 20 menurut Arikunto, (2003 : 100) adalah :

$\mathrm{r}_{11}=\left(\frac{n}{n-1}\right)\left(\frac{S^{2}-\sum p q}{S^{2}}\right)$

Keterangan :

$\mathrm{r}_{11}=$ reliabilitas tes secara keseluruhan

$\mathrm{p}=\quad$ Proporsi subjek yang menjawab item dengan benar

$\mathrm{q}=$ Proporsi subjek yang menjawab item dengan salah

$\sum p q=$ jumlah perkalian $\mathrm{p}$ dan $\mathrm{q}$

$\mathrm{n} \quad=$ banyak item

$\mathrm{S} \quad=$ standar deviasi tes

Untuk menentukan harga reliabilitas tes maka harga tersebut dikonformasikan dengan tabel harga kritik $\mathrm{r}$ tabel Product Moment dengan $\alpha=0,05$, jika $r_{\text {hitung }}>r_{\text {tabel }}$ tes dinyatakan reliabel. 


\section{Teknik Analisis Data}

Menentukan nilai rata-rata dan simpangan baku

Untuk menghitung rata-rata digunakan rumus menurut (Sudjana, $2005: 67)$ yaitu :

$\bar{X}=\frac{\sum x_{i}}{N}$

Keterangan : $\overline{\mathrm{X}}=$ Rata-rata nilai kelas

$\mathrm{fi}=$ Jumlah nilai siswa

$\mathrm{N}=$ Jumlah siswa

Selanjutnya dihitung simpangan baku dengan rumus sebagai berikut :

Dengan : $s=\frac{n \sum x i^{2}-\left(\sum x i\right)^{2}}{N(N-1)}$

( Sudjana, 2005 :

94 )

\section{Uji Normalitas}

Bertujuan untuk melihat apakah sampel berasal dari populasi yang berdistribusi normal atau tidak. Untuk menguji digunakan uji Lifiefors menurut Sudjana (2005:466). Langkah-langkah yang dilakukan untuk pengujian tersebut adalah :

Data $\mathrm{X}_{1}, \mathrm{X}_{2}, \mathrm{X}_{3}, \ldots \ldots \ldots \ldots . . . \mathrm{X}_{n}$ dijadikan bilangan baku $\mathrm{Z}_{1}, \mathrm{Z}_{2}, \mathrm{Z}_{3}, \ldots \ldots . . \mathrm{Z}$

Dengan menggunakan rumus $Z_{1}=\frac{X_{1-} \bar{X}}{s}$ dimana $: \mathrm{X}_{1}=$ responden $\mathrm{X}_{1}, \mathrm{X}_{2}, \mathrm{X}_{3}, \ldots \ldots \ldots \ldots . . . \mathrm{X}_{n}$

$\bar{X}=$ rata-rata perhitungan

$\mathrm{S}=$ simpangan baku

Menghitung peluang $\mathrm{F}(\mathrm{Zi})=\mathrm{T}(\mathrm{Z}<\mathrm{Zi})$

Menghitung proporsi $Z_{1}, Z_{2}, Z_{3}, Z_{n}$ yang lebih kecil atau sama dengan $X i$. Jika proporsi ini dinyatakan oleh

$\mathrm{S}(\mathrm{Zi})$ maka:

$\mathrm{S}(\mathrm{Zi})=\frac{\text { banyaknyaZ, } Z_{2}, Z_{3} \ldots . . Z_{n} \text { yang } \leq Z_{1}}{N}$

Menghitung selisih $F\left(Z_{1}\right)-S\left(Z_{1}\right)$ yang diambil harga mutlaknya.

Mengambil harga mutlak yang paling besar dari selisih itu dan disebut Lo.

Hipotesis normalitas diterima jika harga Lo $<$ Li tabel untuk uji Liliefors dengan $\alpha=0,05$ dan normalitas ditolak jika harga Lo > Li tabel.

\section{Uji Homogenitas}

Uji homogenitas bertujuan untuk mengetahui apakah data sampel memiliki varians yang homogen apa tidak. Uji homogenitas menggunakan uji F. Langkah-langkah yang dilakukan untuk menguji homogenitas dengan rumus:

$F=\frac{\text { Variansterbesar }}{\text { Varianste } k \text { ecil }}$ atau $F=\frac{S_{1}^{2}}{S_{2}{ }^{2}}$

(Sudjana, $2005: 249$ )

Keterangan:

$\mathrm{F}=\mathrm{Uji} \mathrm{F}$

$\mathrm{S}_{1}{ }^{2}=$ Varians terbesar

$\mathrm{S}_{2}{ }^{2}=$ Varians terkecil 
Kriteria pengujian : terima Ho jika $\mathrm{F}_{(1-\alpha)\left(n_{1}-1\right)}<\mathrm{F}<\mathrm{F}_{1 / 2} \alpha\left(n_{1}-1, n_{2}-1\right)$ atau jika $\mathrm{F}_{\text {hitung }}<\mathrm{F}_{\text {tabel }}$ dimana $\mathrm{F}_{\text {tabel }}$ didapat dari daftar distribusi $\mathrm{F}$ dengan $\alpha=0,01$.

\section{Pengujian Hipotesis}

\section{Uji kesamaan rata-rata pretes}

Untuk menguji hipotesis penelitian digunakan uji-t dua pihak yaitu untuk mengetahui kesamaan kemampuan awal siswa pada kedua kelompok sampel, jika data penelitian berdistribusi normal dan homogen maka hipotesis yang diuji adalah:

H0 $: \overline{X_{1}}=\overline{X_{2}}$ : Kemampuan awal siswa pada kelas eksperimen sama dengan kemampuan awal siswa pada kelas kontrol

Ha $: \overline{X_{1}} \neq \overline{X_{2}}$ : Kemampuan awal siswa pada kelas eksperimen tidak sama dengan kemampuan awal siswa pada kelas kontrol

$t=\frac{\bar{X}_{1}-\bar{X}_{2}}{S \sqrt{\frac{1}{n_{1}}+\frac{1}{n_{2}}}}$

(Sudjana, 2005:239)

Dimana $\mathrm{S}$ adalah varians gabungan yang dihitung dengan rumus :

$S^{2}=\frac{\left(n_{1}-1\right) S_{1}^{2}+\left(n_{2}-1\right) S_{2}^{2}}{n_{1}+n_{2}-2}$

Kriteria pengujian : terima Ho jika $-t_{1-1 / 2 \alpha}<\mathrm{t}<t_{1-1 / 2 \alpha}$ didapat dari daftar distribusi t dengan $\mathrm{dk}=\mathrm{n}_{1}+\mathrm{n}_{2}-2$ dan $\alpha=0,05$. Berarti kemampuan awal siswa pada kelas eksperimen sama dengan kemampuan awal siswa pada kelas kontrol. Untuk harga t lainnya maka Ho ditolak, terima Ha. Berarti kemampuan awal siswa pada kelas eksperimen tidak sama dengan kemampuan awal siswa pada kelas kontrol.

Uji kesamaan rata-rata postes

Untuk mengetahui pengaruh dari pendekatan open-ended terhadap kemampuan berpikir kreatif maka digunakan uji satu pihak yaitu :

Ho $: \overline{X_{1}}=\overline{X_{2}}$ : Hasil belajar siswa pada kelas eksperimen dan kelas kontrol sama, berarti tidak ada pengaruh pendekatan pembelajaran open-ended.

Ha $: \overline{X_{1}}>\overline{X_{2}}$ : Hasil belajar siswa pada kelas eksperimen lebih besar dari kelas kontrol, berarti ada pengaruh pendekatan pembelajaran open-ended.

$t=\frac{\bar{X}_{1}-\bar{X}_{2}}{S \sqrt{\frac{1}{n_{1}}+\frac{1}{n_{2}}}}$

(Sudjana, 2005:239)

Dimana $\mathrm{S}$ adalah varians gabungan yang dihitung dengan rumus :

$S^{2}=\frac{\left(n_{1}-1\right) S_{1}^{2}+\left(n_{2}-1\right) S_{2}^{2}}{n_{1}+n_{2}-2}$

Keterangan :

$\mathrm{t}=$ distribusi $\mathrm{t}$

$\bar{X}_{1}=$ rata-rata hasil belajar matematika pada kelas eksperimen

$\bar{X}_{2}=$ rata-rata hasil belajar matematika pada kelas kontrol

$\mathrm{n}_{1}=$ Jumlah siswa kelas eksperimen

$\mathrm{n}_{2}=$ Jumlah siswa kelas kontrol

$\mathrm{S}_{1}{ }^{2}=$ Varians kelas eksperimen 
$\mathrm{S}_{2}{ }^{2}=$ Varians kelas kontrol

$\mathrm{S}^{2}=$ Varians dua kelas sampel

Kriteria pengujian :

Terima Ho jika $\mathrm{t}<\mathrm{t}_{1-\alpha}$ dimana $\mathrm{t}_{1-\alpha}$ didapat dari daftar distribusi $\mathrm{t}$ dengan peluang ( $\left.1-\alpha\right)$ dan $\mathrm{dk}=\mathrm{n}_{1}+\mathrm{n}_{2}-2$ dan $\alpha=0,05$. Berarti hasil belajar matematika siswa pada kelas eksperimen sama dengan hasil belajar siswa pada kelas kontrol. Jika hasil analisis menunjukkan harga t lainnya maka tolak Ho, terima Ha. Berarti hasil belajar matematika siswa pada kelas eksperimen lebih besar daripada hasil belajar siswa pada kontrol. Maka pendekatan pembelajaran open-ended berpengaruh terhadap kemampuan berpikir kreatif..

\section{Uji Coba Instrumen Penelitian}

Sebelum instrumen berupa perangkat test digunakan untuk mengumpulkan data, terlebih dahulu dilakukan uji coba test untuk mengukur tingkat kesukaran, soal daya pembeda soal, validitas test dan reliabilitas test. Uji coba ini dilakukan di kelas X.

Tingkat kesukaran soal

Dalam melakukan perhitungan tingkat kesukaran soal terlebih dahulu butir soal dianalisis, berdasarkan hasil pengujian dari 30 soal diperoleh tingkat kesukaran test yaitu 5 soal dalam kategori mudah, 18 butir soal sedang, dan 7 butir soal sukar.

\section{Daya Pembeda Soal}

Berdasarkan hasil analisis butir item untuk siswa kelompok atas dan siswa kelompok bawah maka dapat dicari daya pembeda dari masing-masing soal, sehingga dari 30 soal yang telah diujikan diperoleh 3 butir soal dalam kategori jelek sekali, 7 soal kategori jelek, 16 soal kategori cukup dan 4 soal kategori baik.

Validitas test

Berdasarkan hasil uji coba test maka dapat dicari $\mathrm{r}_{\mathrm{xy}}$ dari masing-masing soal untuk menentukan soal tersebut valid atau tidak valid, sehingga 30 soal yang diujikan diperoleh yang tidak valid sebanyak 10 soal, dan yang valid sebanyak 20 soal, soal yang valid inilah akan digunakan untuk menjaring data penelitian.

Reliabilitas Test

Dari tabel hasil uji coba dicari harga $r_{\text {II }}$ kemudian dikonsultasikan dengan $r_{\text {tabel }}$, maka diperoleh $r_{\text {hitung }}$ $(0,666)>r_{\text {tabel }}(0,320)$ sehingga dapat dikatakan soal test reliabel.

\section{Angket Kepribadian Kreatif}

Alat ukur kepribadian kreatif ini diambil dari inventarisasi tanggapan kreatif karya Munandar (1977) yang dikumpulkan dari sifat-sifat orang kreatif yang sudah terkenal di seluruh dunia. Karena alat ukur ini sudah terstandar (standardized) yang sudah disusun secara cermat dan diujicobakan berulang kali, maka angket pada dasarnya tidak perlu diujicoba lagi (Arikunto, 2002).

\section{HASIL PENELITIAN}

Data Hasil Pre tes dan Post - test Siswa

Sampel sebelum perlakuan diberikan, siswa memperoleh rata-rata nilai hasil belajar pre test seperti yang terlihat pada tabel di bawah ini.

Tabel 4.1. Hasil Belajar Pre Test

\begin{tabular}{|l|l|l|l|}
\hline Kelas & N & X & SD \\
\hline Eksperimen & 30 & 24,6 & 6,51 \\
\hline Kontrrol & 30 & 25,8 & 7,45 \\
\hline
\end{tabular}

Kemudian sampel diberikan perlakuan dengan menggunakan pendekatan pembelajaran Open-Ended ratarata nilai hasil belajar post-test siswa 
Tabel 4.2. Hasil Belajar Pos Test

\begin{tabular}{|l|l|l|l|}
\hline Kelas & N & X & SD \\
\hline Eksperimen & 30 & 59,12 & 6,22 \\
\hline Kontrrol & 30 & 53,33 & 6,26 \\
\hline
\end{tabular}

\section{Uji Hipotesis Nilai Post Test Siswa}

Hasil pengujian hipotesis nilai post test siswa dapat dilihat pada tabel di bawah ini.

Tabel 4.3. Nilai post test siswa

\begin{tabular}{|l|l|l|l|l|l|l|l|}
\hline Kelas & $\mathrm{X}$ & $\mathrm{SD}$ & $\alpha$ & $\mathrm{dk}$ & $\begin{array}{l}\mathrm{t} . \\
\text { hitung }\end{array}$ & t.tabel & Keterangan \\
\hline Eksperimen & 59,12 & 6,22 & \multirow{2}{*}{0,05} & 58 & 3,7 & 2,00 & $\begin{array}{l}\text { Tolak Ho } \\
\text { Ada penga } \\
\text { ruh }\end{array}$ \\
\hline Kontrol & 53,33 & 6,26 & & & \\
\hline
\end{tabular}

Dengan membanding antara $t_{\text {hitung }}$ dengan $t_{\text {tabel }}$ diperoleh $t_{\text {hitung }}>t_{\text {tabel }}$ atau 3,7 $>2,00$, sehingga Ha diterima dan Ho ditolak. Disimpulkan bahwa ada pengaruh yang signifikan dengan menggunakan pendekatan pembelajaran open-ended terhadap kemampuan berpikir kreatif matematika siswa di kelas X Madrasah Aliyah Pesantren Daar Al Uluum Asahan Tahun Pelajaran 2014/2015.

Hasil belajar siswa sebelum diberi perlakuan memiliki rata-rata 24,6. Hasil ini memiliki nilai yang lebih rendah dibandingkan dengan hasil belajar siswa setelah diberi perilaku yang memiliki rata-rata 59,12. Perlakuan diberikan dengan menggunakan pendekatan pembelajaran open-ended. Hasil belajar diperoleh dari nilai test objektif siswa yang merupakan tahap evaluasi dari pendekatan pembelajaran yang digunakan peneliti sebelumnya siswa diajak menemukan deskripsi mereka mengenai materi pokok yang diajarkan.

Dari nilai rata-rata yang diperoleh dapat dihitung standart deviasi, varians serta nilai uji hipotesis rata-rata dari penelitian ini. Dari perhitungan uji hipotesis tersebut diperoleh nilai 3,7. Nilai ini merupakan nilai $t_{\text {hitung }}>t_{\text {tabel }}$, diperoleh hasil hipotesis dengan kesimpulan bahwa adanya pengaruh yang signifikan antara pendekatan pembelajaran open-ended terhadap kemampuan berpikir kreatif matematika siswa kelas X Madrasah Aliyah Pesantren Daar Al Uluum Asahan Tahun Pelajaran 2014/2015.

\section{Sikap Siswa terhadap Pembelajaran}

Berdasarkan hasil jawaban siswa terhadap angket sikap siswa, secara umum siswa menunjukkan sikap positif terhadap pelajaran matematika, pembelajaran dengan pendekatan open-ended dan soal-soal openended yang diberikan selama proses pembelajaran. Lebih dari $80 \%$ siswa memperlihatkan sikap positif terhadap pelajaran matematika, lebih dari $75 \%$ siswa menunjukkan sikap positif terhadap pembelajaran pendekatan open-ended, dan lebih dari 70\% siswa menunjukkan sikap positif terhadap soal-soal open-ended yang diberikan. Dalam suasana pembelajaran dengan pendekatan open-ended, siswa merasakan kesenangan dengan pelajaran yang diberikan, termotivasi untuk mengikuti pelajaran dan merasa tertantang dengan soalsoal yang diberikan selama proses pembelajaran. Dengan demikian pembelajaran dengan pendekatan openended memberikan suasana belajar yang menyenangkan sehingga memungkinkan siswa lebih leluasa dalam mengembangkan kemampuan berpikir khususnya kemampuan berpikir kreatif. 


\section{PENUTUP}

Hasil belajar matematika di kelas X Madrasah Aliyah Pesantren Daar Al Uluum tahun pelajaran 2014/ 2015 yang diajar sebelum menggunakan pendekatan pembelajaran open-ended sebagai pendekatan pembelajaran adalah dengan rata-rata 24,6 sedangkan hasil belajar siswa setelah diajar dengan pendekatan pembelajaran open-ended memiliki nilai rata-rata 59,12. Hasil ini menunjukkan bahwa adanya pengaruh yang signifikan penggunaan pendekatan pembelajaran open-ended terhadap kemampuan berpikir kreatif siswa di kelas X Madrasah Aliyah Pesantren Daar Al Uluum tahun pelajaran 2014/2015. Terdapat perbedaan hasil belajar siswa yang diajar dengan pendekatan pembelajaran open-ended dan yang diajar dengan konvensional bahwa kemampuan berpikir kreatif siswa yang diajar dengan menggunakan pendekatan pembelajaran open-ended lebih tinggi dibandingkan dengan kemampuan berpikir kreatif siswa yang diajar dengan menggunakan pembelajaran Konvensional di kelas X Madrasah Aliyah Pesantren Daar Al Uluum tahun pelajaran 2014/ 2015.

\section{SARAN}

Dari hasil penelitian di atas maka penulis menuliskan beberapa saran sebagai berikut :

Bagi guru matematika dapat mempertimbangkan pendekatan pembelajaran open-ended sebagai pendekatan pembelajaran.

Bagi peneliti: hasil penelitian ini nantinya dapat dijadikan sebagai acuan/referensi (penelitian yang relevan) pada penelitian yang sejenis.

Bagi siswa: Pendekatan open-ended ini diharapkan mampu meningkatkan kemampuan berpikir kreatif dan self esteem siswa.

\section{RUJUKAN}

Arikunto, S. 2003. Prosedur Penelitian Suatu pendekatan Praktek. Edisi Revisi V. Jakarta: Rineka Cipta.

Balka, D.S 1974. "Creative ability in Mathematics". Arithmetic Teacher. 21 (70), 633-836.

Hadamard, J. 1945. Essay on Psychology of Invention in the Mathematical Field. Princeton, NJ: Princeton University Press.

Heddens, J.W. dan Speer, W.R. 1995. Concepts and Classroom Methods, Today's Mathematics (eight ed). New York: Macmillan Publishing Company.

Krutetskii, V.A. 1976. The Psychology of Mathematical Abilities in Schoolchildren. Chicago: University of Chicago Press.

Pehkonen, E.1997. "Fostering Mathematical Creativity". International Review on Mathematical Education. 29 (3) [Online]. http://www.fizkar/sruhe.de/fiz/publications/zdm973a.html

Schoenfeld, A.H.1992. "Learning to Think Mathematically: Problem Solving, Metacognition, and Sense Making in Mathematics." Handbook of Research on Mathematics Teaching and Learning. New York: McMilan Publishing Co.

Sudjana. 2005. Metoda Statistika. Bandung:Tarsito

Suherman, S. dkk. 2003. Strategi Pembelajaran Matematika Kontemporer (coomon textbook). JICA Bandung : Universitas Pendidikan Indonesia.

Supriadi, D. 1997. Kreativitas, Kebudayaan \& Perkembangan IPTEK. Bandung: Alfabeta. 